\title{
MULTIPLE REGRESSION ANALYSIS IN TITLE VII CASES: A STRUCTURAL APPROACH TO ATTACKS OF "MISSING FACTORS" AND "PRE-ACT DISCRIMINATION"
}

\author{
BARBARA A. NORRIS* \\ I

\section{INTRODUCTION}

The necessity for increasingly sophisticated evidentiary approaches to proving class-based employment discrimination claims under Title VII of the Civil Rights Act of $1964^{1}$ has led to increasing reliance on statistics by plaintiffs and defendants alike. One of the most sophisticated statistical techniques used to date in employment discrimination law is multiple regression analysis. The application of multiple regression analysis offers great and, perhaps, the only potential for addressing certain types of Title VII claims, particularly wage discrimination claims. Recent court decisions, however, have made abundantly clear that evidentiary presentations based on multiple regression will be carefully scrutinized, and that inadequately prepared statistics will be rejected. In the legal context, multiple regression is both a Mecca and a minefield.

Defendants have used a variety of strategies to attack evidence of illegal discrimination presented through plaintiffs' regression studies. Two modes of attack have been the most frequently successful: the claim that plaintiffs' regression statistics fail to account for important explanatory factors; and the claim that plaintiffs' statistics are skewed by the inclusion of data on persons hired prior to the actionable statutory period of Title VII.

The courts of appeal have taken divergent approaches to evaluating such attacks, at times discounting plaintiffs' statistics in summary fashion. The Supreme Court has not yet established a universal standard of review. Two recent cases in the Court of Appeals for the District of Columbia, Trout $v$. Lehman ${ }^{2}$ and Segar $v$. Smith, ${ }^{3}$ have provided a strong theoretical approach to the review of cases relying on multiple regression analysis consistent with the

\footnotetext{
Copyright $\odot 1987$ by Law and Contemporary Problems

A.B. Harvard, 1977; J.D. University of California, Berkeley, 1983. Presently at Burr, Pease \& Kurtz, Anchorage, Alaska.

1. 42 U.S.C. \& $2000 \mathrm{e}$ to $2000 \mathrm{e}-17$ (1982).

2. 702 F.2d 1094 (D.C. Cir. 1983), vacaled, 465 U.S. 1056 (1984).

3. 738 F.2d 1249 (D.C. Cir. 1984), cert. denied, 471 U.S. 1115 (1985).
} 
analytical structure established under Title VII. Most recently, Segar has proposed that an integrated approach using disparate treatment and disparate impact theories simultaneously is appropriate for review of complex statistical cases. ${ }^{4}$

This article will begin with a brief review of how multiple regression analysis works and of the Title VII context in which that analysis must operate. It will then consider the defendants' typical "missing factor" and "pre-Act discrimination" attacks on plaintiffs' statistical showing of discrimination. Finally, the article will explore how plaintiffs can use the integrated disparate treatment/impact analytical model to counter defendants' attacks. Additionally, this article suggests that plaintiffs should introduce the "continuing violation" theory into the multiple regression arena where pre-Act discrimination is an issue. These two analytical tools will help plaintiffs to address the full extent of discrimination revealed by multiple regression studies.

II

\section{Multiple Regression: The Statistical Technique and Its LEgal Context}

A. The Technique

Multiple regression analysis is a statistical technique used to indicate how a number of different factors acting together influence a particular outcome. ${ }^{5}$ In the employment discrimination context it is most frequently used to indicate what factors influence individuals' salaries. ${ }^{6}$ The following brief explanation of how the technique works is intended only to provide sufficient background to allow the unfamiliar reader to follow the subsequent discussion of the defendants' attacks against the technique. More complete explanations of the statistical methodology of multiple regression are available in the literature. ${ }^{7}$ The following example indicates how multiple regression is usually applied in the employment discrimination context.

4. Id. at 1265-73. See infra section III; see also cases cited infra notes $126-47$ and accompanying text.

5. For a more thorough treatment of how multiple regression analysis works, see Fisher, Multiple Regression in Legal Proceedings, 80 Colum. L. REv. 702 (1980); Levin \& Robbins, Urm Models for Regression Analysis, with Applications to Employment Discrimination Studies, LAw \& ConTEMP. ProBs., Autumn 1983, at 247; Note, Beyond the Prima Facie Case in Employment Discrimination Law: Statistical Proof and Rebuttal, 89 Harv. L. Rev. 387 (1975); Note, Title VII, Multiple Linear Regression Models, and the Courts: An Analysis, Law \& Contemp. Probs., Autumn 1983, at 283. See generally D. Baldus \& J. Cole, Statistical. Proof of Discrimination ch. 8 (1980 \& Supp. 1983); T. Wonnacott \& R. Wonnacott, InTRoductory Statistics (4th ed. 1985).

6. See, e.g., Segar v. Smith, 738 F.2d 1249, 1261-63 (D.C. Cir. 1984), cert. denied, 471 U.S. 1115 (1985); Craik v. Minnesota State Univ. Bd., 731 F.2d 465, 478-80 (8th Cir. 1984); Trout v. Lehman, 702 F.2d 1094, 1099 (D.C. Cir. 1983), vacated, 465 U.S. 1056 (1984); Valentino v. United States Postal Serv., 674 F.2d 56, 69 (D.C. Cir. 1982); Allen v. Prince George's County, 538 F. Supp. 833, 848 (D. Md. 1982), aff'd, 737 F.2d 1299 (4th Cir. 1984); see also Bazemore v. Friday, 106 S. Ct. 3000 (1986) (per curiam); cases cited infra notes 126-47.

7. See sources cited supra note 5 . 
An initial look at one company's personnel system might indicate that years of education, years of experience, and performance evaluation scores all influence an individual's salary. Female employees at this company believe that they are being paid less, given their qualifications, than male employees. Multiple regression analysis permits an estimation, on the average, of how much each of the factors-education, experience, and performance evaluation scores-influences salary. In addition, it permits an examination of whether sex is a factor in setting salary.

To apply multiple regression analysis, data on the education, experience, performance evaluations, sex, and salaries of the company's employees are entered into a computer. A standard statistical program ${ }^{8}$ will perform the necessary calculations and provide information in the form of an equation indicating how much each of the chosen factors influences salary. For example, the computer printout will give values for the coefficients of the following standard equation:

$$
\mathrm{S}=\mathrm{k}+\mathrm{ax}_{1}+\mathrm{bx}_{2}+\mathrm{cx}_{3}+\mathrm{dx}_{4}+\mathrm{u} \text {. }
$$

In this equation, $S$ is monthly salary; $k$ is a constant; $a$ is the coefficient associated with $x_{1}$, years of education; $b$ is the coefficient associated with $x_{2}$, years of experience; $c$ is the coefficient associated with $x_{3}$, last performance evaluation (scale of 1 , low, to 6 , high); $d$ is the coefficient associated with $x_{4}$, sex ( 1 if male, 0 if female); and $u$ is a random error term representing the presumably neutral effects of factors left out of our model.

The printout might give the following values:

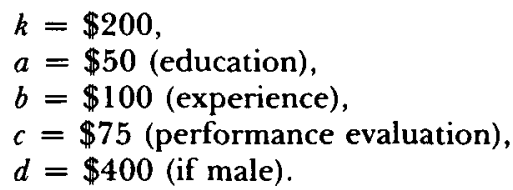

Thus, a person with a college degree (sixteen years of education), three years of experience, a performance evaluation of 4 , and who is male, will be paid on average:

$$
\begin{aligned}
& S=\$ 200+(\$ 50)(16)+(\$ 100)(3)+(\$ 75)(4)+\$ 400, \\
& S=\$ 200+\$ 800+\$ 300+\$ 300+\$ 400, \\
& S=\$ 2,000 \text { per month. }
\end{aligned}
$$

A female employee with exactly the same qualifications, according to this model, would earn only $\$ 1,600$ per month because a factor of $\$ 400$ additional dollars per month is associated with being male.

The computer printout will also provide information indicating the probability that the results achieved are due to chance, rather than the factor in question. This information is usually in the form of a $t$ statistic or an $F$ statistic. The values on the printout can be checked against standard statistical tables to see whether the results in question are statistically significant. In the social sciences, results are generally considered statistically

8. For example, the widely available software package, Statistical Package for the Social Sciences (SPSS), includes a regression program suitable for these purposes. 
significant if the likelihood that they occurred by chance is no more than one in twenty, or .05 . This corresponds to a ninety-five percent confidence level. Some results are reported as significant if they could have occurred by chance only one time in a hundred, or .01 . This corresponds to a ninety-nine percent confidence level. Courts generally have been willing to consider statistics which are significant at the .05 level as legally significant evidence, in the absence of flaws in the statistical methodology used. ${ }^{9}$ Thus, in the above example, if the $\$ 400$ factor associated with being male was determined to be statistically significant, and the statistical methodology was acceptable, it would raise an inference of sex-based wage discrimination.

Because multiple regression statistics have the technical capacity to identify discriminatory influences from among the combined effects of a set of factors acting simultaneously, they have powerful and useful potential in Title VII litigation. Multiple regression can even indicate the extent to which a protected group is damaged by a discriminatory practice. Multiple regression can also reveal discrimination where no direct comparisons are possible between males and females or blacks and whites because they do not have precisely the same qualifications.

The probative value of statistical techniques such as multiple regression, of course, can be no greater than their methodological reliability. In practice, methodological issues form the crux of a court's problems in deciding how much weight, if any, to afford to statistical presentations based on multiple regression analysis. In the past few years, many statistical presentations by plaintiffs which purported to show statistically significant discrimination have been rejected by the courts as methodologically flawed. ${ }^{10}$ Defendants' statistics have also been rejected on methodological grounds. ${ }^{11}$

As will be discussed in section III, two of the key points of methodological attack involve the choice of explanatory factors used in the regression analysis and the proper limitation of data to be used in the analysis. The debate over these issues does not arise from statistical theory alone, but also from the application of statistical theory within the relevant limits of Title VII litigation.

\section{B. Burdens of Proof in the Title VII Context}

Title VII of the Civil Rights Act of $1964^{12}$ prohibits discrimination on the basis of race, color, religion, sex, or national origin. It specifically covers hiring, discharge, compensation, terms, conditions, and privileges of

9. Segar v. Smith, 738 F.2d 1249, 1283 n.28 (D.C. Cir. 1984), cert. denied, 471 U.S. 1115 (1985); Craik v. Minnesota State Univ. Bd., 731 F.2d 465, 475 n.13 (8th Cir. 1984).

10. See, e.g., Coser v. Moore, 739 F.2d 746, 752-54 (2d Cir. 1984); Allen v. Prince George's County, 737 F.2d 1299, 1305 (4th Cir. 1984); Valentino v. United States Postal Serv., 674 F.2d 56, 68-71 (D.C. Cir. 1982); EEOC v. International Business Machs. Corp., 583 F. Supp. 875, 897-99 (D. Md. 1984). But see Bazemore v. Friday, 106 S. Ct. 3000 (1986) (per curiam).

11. See, e.g., Segar v. Smith, 738 F.2d 1249, 1284-86 (D.C. Cir. 1984), cert. denied, 471 U.S. 1115 (1985); Trout v. Lehman, 702 F.2d 1094, $1105-06$ (D.C. Cir. 1983), vacated, 465 U.S. 1056 (1984).

12. 42 U.S.C. $\$ 2000 \mathrm{e}-2(\mathrm{a})(1982)$. 
employment. ${ }^{13}$ Litigation under Title VII generally proceeds under one of two evidentiary theories: the disparate treatment theory or the disparate impact theory. ${ }^{14}$

1. Disparate Treatment. The disparate treatment theory is utilized by plaintiffs who are attempting to show that members of a protected class have been treated less favorably by an employer than other similarly situated individuals. While disparate treatment theory requires the plaintiffs to prove intentional discrimination, this intent is inferred in practice by circumstantial evidence of differential treatment.

For a discrimination case brought by an individual under the disparate treatment theory, the Supreme Court set out the order and burdens of proof of the parties in Texas Department of Community Affairs $v$. Burdine. ${ }^{15}$ First, the plaintiff must make out a prima facie case. The particular facts necessary to make out a prima facie case vary with the circumstances, ${ }^{16}$ but the plaintiff must raise at least an inference of discrimination by eliminating the most obvious nondiscriminatory reasons for the employment action in question. The burden of going forward with the evidence then shifts to the employer, which must put forward a "legitimate, non-discriminatory reason" 17 for its actions. The plaintiff may then attempt to show that the employer's explantion is merely a pretext for discrimination. The burden of proof always remains with the plaintiff to show discrimination by a preponderance of the evidence. ${ }^{18}$

Despite the apparently clear-cut explanation of the order and burdens of proof supplied by the Supreme Court for individual cases, several appellate courts have questioned Burdine's application to class-based disparate treatment claims. To prevail in a class-based claim, the plaintiffs must demonstrate that the defendant engaged in an "pattern or practice" of discrimination not merely by proving isolated incidents of discrimination, but rather by showing that discrimination was the "defendant's standard operating procedure-the regular rather than the unusual practice." 19 These are the types of cases in which multiple regression analysis is typically used.

13. Part of Title VII states:

It shall be an unlawful employment practice for an employer

(1) to fail or refuse to hire or to discharge any individual, or otherwise to discriminate against any individual with respect to his compensation, terms, conditions, or privileges of employment, because of such individual's race, color, religion, sex, or national origin; or

(2) to limit, segregate, or classify his employees or applicants for employment in any way which would deprive or tend to deprive any individual of employment opportunities or otherwise adversely affect his status as an employee, because of such individual's race, color, religion, sex, or national origin.

42 U.S.C. \& 2000e-2(a) (1982).

14. See International Bhd. of Teamsters v. United States, 431 U.S. 324, 335 n.17 (1977).

15. 450 U.S. 248, 252-56 (1981).

16. McDonnell Douglas Corp. v. Green, 411 U.S. 792, 802 n.13 (1973).

17. Id. at 802 .

18. Burdine, 450 U.S. at 253.

19. International Bhd. of Teamsters v. United States, 431 U.S. 324, 336 (1977). 
In pattern or practice cases, several courts have held that not only the burden of presenting evidence, but the burden of proof shifts to the employer once the plaintiff has made a prima facie case. As Judge Higgenbotham stated in his 1981 district court decision in Vyanich v. Republic National Bank, 20 "[i]n a complex class action, utilizing statistical proof and counterproof, the value of the Burdine sequence-to highlight the issues in contest-is about as relevant as a minuet is to a thermonuclear battle." 21 The very use of complex statistical proof in Title VII cases is requiring some changes in the evidentiary approaches needed to handle it.

Judge Higgenbotham's view has met with accord in the Eleventh Circuit, ${ }^{22}$ and has been cited with approval by the Eighth Circuit. ${ }^{23}$ Some other circuits have continued to employ the traditional Burdine sequence in both classwide and individual cases. ${ }^{24}$

Where a court transfers the burden of proof to the defendants to combat the plaintiff's prima facie case, this transfer appears to go hand in hand with an elevation of the standard of proof required for plaintiff's prima facie case. As the Eighth Circuit stated in a footnote in Craik v. Minnesota State University Board, ${ }^{25}$

The prima facie case established by a finding that an employer is guilty of a pattern or practice of discrimination goes far beyond the prima facie case contemplated by McDonnell Douglas and Burdine .... ([Under the Burdine standard] "[ $\mathrm{t}]$ he burden of establishing a prima facie case of disparate treatment is not onerous." 26

Evidently the Eighth Circuit concludes that the difficult nature of raising even an inference of discrimination on a classwide basis justifies a higher rebuttal standard than that appropriate for individual cases of discrimination.

2. Disparate Impact. The second major analytical approach utilized in Title VII litigation is based on the disparate impact theory. Under disparate impact, the plaintiff must establish a prima facie case by identifying a facially neutral policy used by the employer which has a disproportionately negative effect on the plaintiff's protected group. ${ }^{27}$ This disproportionately negative impact is demonstrated with statistics. The employer may rebut the prima facie case by demonstrating that the policy producing the disparate impact is justified by business necessity. ${ }^{28}$ This justification cannot stand, however, if

20. 521 F. Supp. 656 (N.D. Tex. 1981), vacated and remanded on other grounds, 723 F.2d 1195 (5th Cir. 1984).

21. Id. at 661 .

22. See Perryman v. Johnson Prods. Co., 698 F.2d 1138, 1143 (11 th Cir. 1983).

23. Craik v. Minnesota State Univ. Bd., 731 F.2d 465, 470 n.7 (8th Cir. 1984).

24. See, e.g., Coser v. Moore, 587 F. Supp. 572 (E.D.N.Y. 1983), aff'd, 739 F.2d 746 (2d Cir. 1984).

25. 731 F.2d 465 (8th Cir. 1984).

26. Id. at $471 \mathrm{n} .9$ (quoting Texas Dep't of Community Affairs v. Burdine, 450 U.S. 248, 253 (1981)).

27. See, e.g., Griggs v. Duke Power Co., 401 U.S. 424 (1971).

28. Id. at 431 . 
the plaintiff can suggest a less discriminatory alternative which will accomplish the business purpose. ${ }^{29}$

Just as the circuits have split with respect to the order and burdens of proof in class-based disparate treatment cases, they are also in disagreement about the order and burdens of proof in disparate impact cases. The Third Circuit embraces a Burdine-like approach in which a mere inference that a discriminatory criterion was used in an employment decision is sufficient to force the defendant to suggest a business justification. ${ }^{30}$ The ultimate burden of persuasion remains with the plaintiff. The Fifth Circuit has adopted a shifting standard, requiring the defendant to bear the burden of persuasion as to its business necessity defense, once the plaintiff's prima facie case is established. ${ }^{31}$

As in the disparate treatment cases discussed above, the shift of the burden of persuasion to the employer in the disparate impact cases is accompanied by a higher standard for the plaintiff's prima facie case. The plaintiff must not merely raise an inference of discriminatory impact, but must prove that the discriminatory impact exists. ${ }^{32}$

The move by some appellate courts to adjust the standards of proof and rebuttal in statistically based cases indicates an effort to place statistically based evidence in a more workable analytical framework than that already developed for individual cases. The Court of Appeals for the District of Columbia has taken a step beyond the other appellate courts in developing an appropriate analytical framework by proposing an integrated approach using both disparate treatment and disparate impact analysis simultaneously. ${ }^{33}$ Section III of this article explores this new framework, and suggests how it can be applied to the evaluation of defendants' most common attacks on plaintiffs' multiple regression evidence. Using this framework in conjunction with Title VII's continuing violation theory, plaintiffs may be able to extend the power of their multiple regression approach to address a wider range of discrimination.

\section{III}

\section{The Two Key Arguments Used to Undermine Plaintiffs' INFERENCE OF DISCRIMINATION}

The courts are in agreement that in proper circumstances statistical evidence, standing alone, may be sufficient to support a prima facie case of discrimination under Title VII. ${ }^{34}$ On a theoretical level, the courts have

29. Dothard v. Rawlinson, 433 U.S. 321,329 (1977).

30. NAACP v. Medical Center, Inc., 657 F.2d 1322, 1334 (3d Cir. 1981).

31. Johnson v. Uncle Ben's, Inc., 657 F.2d 750, 753 (5th Cir. 1981), cert. denied, 549 U.S. 967 (1982).

32. Id.

33. Segar v. Smith, 738 F.2d 1249, 1265-72 (D.C. Cir. 1984), cert. denied, 471 U.S. 1115 (1985).

34. Hazelwood School Dist. v. United States, 433 U.S. 299, 307-08 (1977). Of course, anecdotal evidence from individuals is always highly desirable for its capacity to "bring the cold numbers convincingly to life." International Bhd. of Teamsters v. United States, 431 U.S. 324,339 (1977). 
become increasingly receptive to complex statistical methodology such as multiple regression analysis. ${ }^{35}$ In practice, however, in many of the cases in which plaintiffs have relied on multiple regression analysis they have failed to prove their claims. ${ }^{36}$ Sometimes, even under liberal standards for a prima facie case, plaintiffs have failed to raise the necessary inference of discrimination. Two key arguments have been used which undermine plaintiffs' attempts to infer discrimination: the claim that plaintiffs have omitted important explanatory variables from their regression equations and the claim that plaintiffs' results are skewed by the inclusion of data on persons hired before Title VII became effective. These problems are recurring ones, and must be carefully addressed by those who aim to use multiple regression analysis successfully.

\section{A. The Omission of Explanatory Factors}

In employment discrimination litigation relying on multiple regression analysis, the most hotly contested issue revolves around the choice of explanatory variables used in the regression equation. ${ }^{37}$ This issue is central because the choice of variables can affect whether or not the analysis reveals any significant discrimination.

Usually the plaintiffs' presentation of a prima facie case involves regressions with salary or grade level as the dependent variable, and a set of job related, experiential factors as the explanatory, or independent, variables. These factors are designed to be indicators of an individual's job capability or value to the employer. Presumably, compensation should be proportionate to job capability. These assumptions are referred to as the human capital theory, which has been studied and documented in the social sciences. ${ }^{38}$

Explanatory factors used by plaintiffs usually include one or more education factors measured by years, degree obtained, or other job related measurement. Experience may be represented by factors such as general work experience, technical work experience, academic work experience,

35. Contrast the statements that statistics "appear to depend in large part on the side producing them" in Stastny v. Southern Bell Tel. \& Tel. Co., 458 F. Supp. 314, 324 (W.D.N.C. 1978), rev'd in part on other grounds, aff'd in part, 628 F.2d 267 (4th Cir. 1980), and comments regarding the "inherently slippery nature" of statistical evidence in Wilkins v. University of Houston, 654 F.2d 388, 395 (5th Cir. 1981), vacated, 459 U.S. 809 (1982) with the statement in Segar v. Smith that requiring anecdotal evidence to accompany all statistics would "reflect little more than a superstitious hostility to statistical proof, a preference for the intuitionistic and individualistic over the scientific and systemic." Segar v. Smith, 738 F.2d 1249, 1278 (D.C. Cir. 1984), cert. denied, 471 U.S. 1115 (1985).

36. E.g., Coser v. Moore, 739 F.2d 746 (2d Cir. 1984); Allen v. Prince George's County, 737 F.2d 1299 (4th Cir. 1984); Valentino v. United States Postal Serv., 674 F.2d 56 (D.C. Cir. 1984).

37. See, e.g., Bazemore v. Friday, i06 S. Ct. 3000, 3008-09 (1986) (per curiam) (Brennan, J., concurring in part for a unanimous court) (issue whether county-to-county differences in salary increases were an appropriate factor) (discussed infra pp. 95-98); Eastland v. Tennessee Valley Auth., 704 F.2d 613 (11th Cir.) (issue whether job category was an appropriate factor), modified on other grounds, 714 F.2d 1066 (11th Cir. 1983); EEOC v. International Business Mach. Corp., 583 F. Supp. 875 (D. Md. 1984) (issue whether seniority, job level, and education were appropriate factors); see also Segar v. Smith, 738 F.2d 1249 (D.C. Cir. 1984) (issue whether specialized experience was appropriate factor), cert. denied, 471 U.S. 1115 (1985).

38. See Segar v. Smith, 738 F.2d 1249, 1261 (D.C. Cir. 1984), cert. denied, 471 U.S. 1115 (1985). 
experience with the present employer, managerial work experience, and so forth. In the academic setting, factors such as number of publications or academic rating of university granting degree may come into play. The choice of explanatory factors must stem from a sound theory as to how employees in the personnel system in question are actually evaluated. ${ }^{39}$ Such a theory must initially be developed from studying the personnel system and, if possible, getting the employer to admit which skills it values.

Defendants usually attempt to rebut plaintiffs' multiple regression statistics by claiming that the plaintiffs have omitted important explanatory factors from their regressions.

If the missing variable is differentially associated with a particular race or sex, its omission may incorrectly lead to a conclusion that discrimination exists. For example, a plaintiff may use only the factors "years of education" and "years of work experience" to explain salary in a set of technical engineering jobs. The regression analysis may show that sex has a statistically significant effect on salary. The defendant may demonstrate that when a factor for "engineering experience" is included in the analysis, it results in eliminating sex as a statistically significant factor. The defendants' statistics reveal that men are paid more because they have, on the average, more engineering experience.

To take an actual example, in EEOC v. International Business Machines Corp., ${ }^{40}$ the plaintiffs presented multiple regression analyses which did not include factors for seniority, job level, or education. This regression analysis indicated race discrimination was present. The defendants, however, persuaded the court that the omitted factors were essential, and that when they were included in defendants' regression analysis the race discrimination effect was eliminated. The court therefore found no discrimination.

While the above examples indicate that the omission of explanatory factors can show discrimination where none exists, it is equally possible for the inclusion of an unjustified explanatory factor to hide discrimination where it does exist. Obviously, in a set of jobs related to foreign language instruction, the inclusion of a factor for engineering experience would be irrelevant. Nonetheless, the inclusion of such a factor could reduce the apparent size and statistical significance of the sex factor because the engineering factor is closely correlated with and tends to act as a proxy for sex.

Because the inclusion of a factor which is correlated with sex or race can reduce or eliminate the statistical significance of sex or race in a multiple regression equation, a defendant wishing to diminish the inference of discrimination may insist that plaintiff's statistics are methodologically flawed by the exclusion of such a factor. Factors which serve as a proxy for sex may not be immediately obvious, but they are, nonetheless, influential. For example, "years of military service" is highly correlated with being male.

39. Id. at 1261-62.

40. 583 F. Supp. 875, 906 (D. Md. 1984). 
Some factors that are correlated with sex or race are so correlated because the employer makes them that way by his own discrimination. Such factors are "tainted" by being under the employer's subjective control, and should be suspect. "Grade level" is a typical example. For instance, the defendant's regression results may show that the factors education, experience, and grade level all affect salary. The primary factor is grade level. It may appear that men and women alike at grade level eight earn $\$ 800$ per month, and at grade level nine, both earn $\$ 900$ per month, and so forth. Plaintiff's statistics, which do not include the grade level factor, show that women are paid substantially less than comparably qualified men. The grade level variable is tainted because the employer determines the grade level of each employee. If women are placed in a lower grade level than men with the same qualifications, then the equal pay between men and women at the same grade level only masks discrimination, which occurs in grade level assignment.

In Craik v. Minnesota State University Board, ${ }^{41}$ the plaintiff class of female faculty members alleged wage discrimination on the basis of sex, and demonstrated this discrimination with multiple regression analyses. The appellate court overruled the magistrate's holding that "rank" should be considered as a factor. Since the court found discrimination with regard to rank assignment, rank was not a valid explanatory factor for salary.

In contrast, in Eastland $v$. Tennessee Valley Authority, ${ }^{42}$ the appellate court affirmed the trial court's rejection of plaintiffs' statistics for failing to account for job category. The plaintiffs had argued that blacks and whites with comparable qualifications were assigned to different jobs on the basis of race so that job category ought not to be a valid factor. The court ignored the argument, and apparently relied on its own belief that the different job categories were simply not comparable.

A classic example of another frequently tainted factor is the job evaluation score. Again, the employer is in control of the evaluation process, and it may be highly discretionary. If women are consistently scored below similarly performing men, then a multiple regression analysis which includes performance evaluation scores may show no discrimination, as indicated in the simple model below:

Plaintiff's Model

Salary $=\$ 100$ (education) $+\$ 50$ (experience) $+\$ 300$ (if male)

Ellen: $\quad \$ 1400=\$ 100(12)+\$ 50(4)+0$

Ed: $\quad \$ 1700=\$ 100(12)+\$ 50(4)+\$ 300$

Conclusion: Ed is paid more due to discrimination.

Defendant's Model

Salary $=\$ 100$ (education) $+\$ 50$ (experience) $+\$ 100$ (performance equation score)

Ellen: $\quad \$ 1500=\$ 100(12)+\$ 50(4)+\$ 100(1)$

Ed: $\quad \$ 1800=\$ 100(12)+\$ 50(4)+\$ 100(4)$

41. 731 F.2d 465, 475 (8th Cir. 1984).

42. 704 F.2d 613, 623-24 (11 th Cir.), modified on other grounds, 714 F.2d 1066 (11th Cir. 1983). 
Conclusion: Ed is paid more due to his better performance.

In order to draw a conclusion as to whether or not "performace evaluation score" in the last example, or any other disputed variable, should validly be included in a regression equation, the court must consider evidence of subjectivity of the factor, its degree of correlation with race or sex, its relationship to the set of jobs in question, and whether the influence of the factor has been adequately accounted for by other explanatory variables. The determination of which party has the burden of presenting evidence or proving the various arguments, rebuttals, and counterarguments related to the choice of variables may well determine which party succeeds in the litigation.

\section{B. Pre- and Post-Statutory Employment Decisions}

Title VII originally became effective for private employers on July 2, 1965, but it did not become applicable to government employers until the Act was amended effective March 24, 1972. The issue of pre-1972 discrimination is still a frequent problem in compensation and promotion cases, in which multiple regression analysis is often used. A similar problem is raised by discrimination which took place prior to the filing of a complaint with the Equal Employment Opportunity Commission. For purposes of back pay, discrimination is only relevant up to two years prior to the date the EEOC complaint was filed.

The following example illustrates how problems can arise. Suppose that an employer based starting salary on only two legitimate factors, education and experience, and valued each at $\$ 100$ per year. Each year he gave continuing employees a $\$ 100$ raise. Prior to 1972 , believing that men deserved to be paid more, the employer discriminatorily paid starting male employees $\$ 300$ more than female employees with the same education and experience. Mark and Mary both started work in 1970. Both had completed high school (twelve years of education) and had one year of experience. For 13 total years of education and experience, Mary was started at $\$ 1,300$ per month. Mark, as a male, was paid an additional $\$ 300$ so he started at $\$ 1,600$ per month. In 1972, the employer stopped discriminating in his initial pay setting. He continued his policy of giving employees a $\$ 100$ raise each year.

As can be seen from Table 1, Mary started out $\$ 300$ behind Mark in pay, and she is still $\$ 300$ behind in 1984 . 


\section{Education \& Experience}

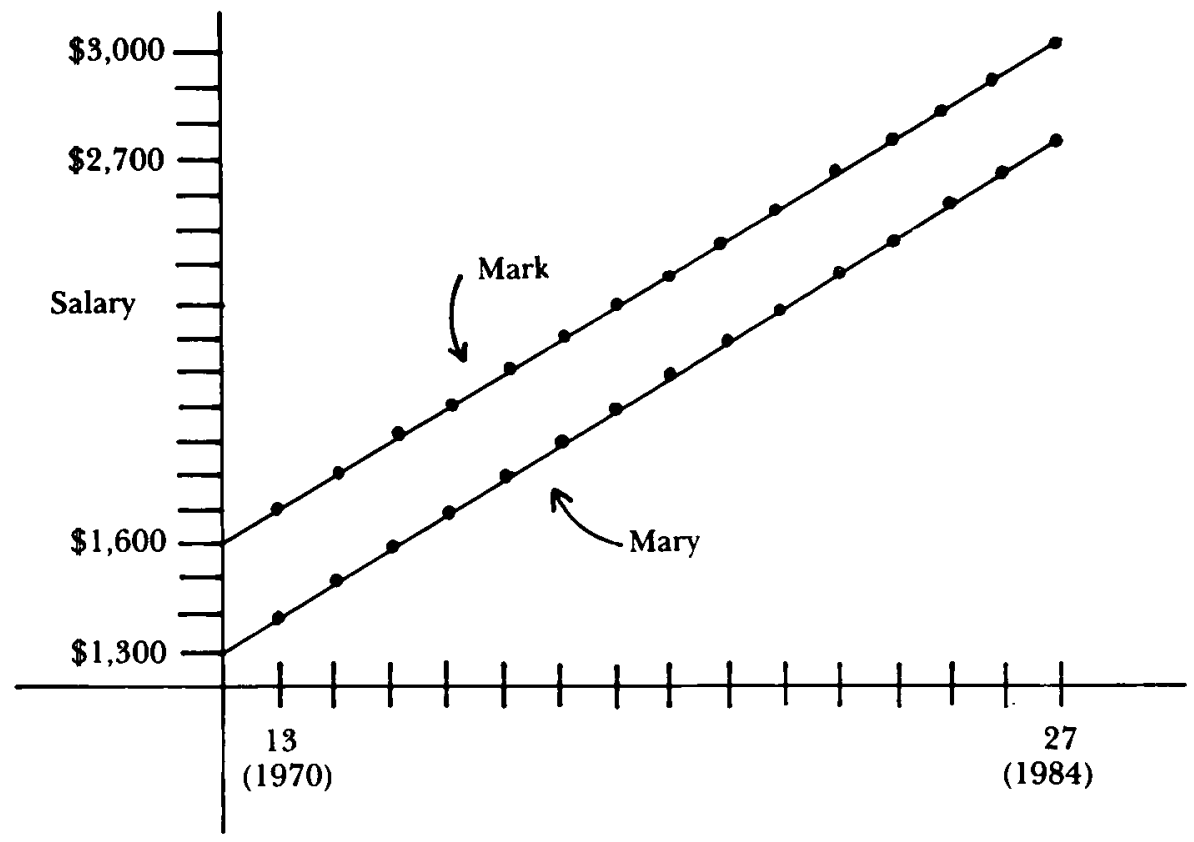

This situation raises an analytical problem. When did the discrimination take place? Mary claims current discrimination in salary, pointing out that present salary is directly correlated with education, experience, and sex as shown in the equation below:

Salary $=\$ 100$ (years education) $+\$ 100$ (yrs. exp.) $+\$ 300$ (if male)

For Mark: $\quad \$ 3,000=\$ 100(12)+\$ 100(14)+\$ 300$

For Mary: $\quad \$ 2,700=\$ 100(12)+\$ 100(14)+0$

The employer will argue that since 1972 he has treated Mark and Mary alike in terms of raises, so there has been no illegal discrimination because pre-1972 discrimination is not actionable.

This same issue is played out on a larger and more complex scale where wages for a whole class of workers are at issue. Some were hired prior to 1972 , some were not. The real-life factors influencing wages are not so clearcut as depicted above, though multiple regression anaysis is capable of developing a reasonable approximation. In a typical case, the plaintiff class will put forward multiple regression analysis results indicating that a set of several presumably legitimate factors, plus sex, act together to influence current salaries. Defendants often attack plaintiffs' statistics for failing to exclude the "effects" of pre-1972 discrimination. ${ }^{43}$

43. Lehman v. Trout, 465 U.S. 1056, $1056-57$ (1984) (Stevens, J., dissenting); Segar v. Smith, 738 F.2d 1249, 1268 (D.C. Cir. 1984), cert. denied, 471 U.S. 1115 (1985); Eastland v. Tennessee Valley Auth., 704 F.2d 613, 623 n.14 (1lth Cir.), modified on other grounds, 714 F.2d 1066 (11th Cir. 1983); Valentino v. United States Postal Serv., 674 F.2d 56, 65 (D.C. Cir. 1982); Sobel v. Yeshiva Univ., 566 F. Supp. 1166, $1182-83$ (S.D.N.Y. 1983); Melani v. Board of Higher Educ., 561 F. Supp. 769, 780 
One way to make sure that pre-1972 or pre-statute of limitations hiring decisions do not influence statistics on current salaries is to eliminate from the data set all persons hired prior to the statutory period. Defendants benefit from such a solution and plaintiffs suffer because all of the employees who have been employed longest are cleansed from the data set, and these are the persons on whom discrimination has had the greatest chance to work its effects. Plaintiffs may well be unconvinced that employers, in post-1972 salary setting, should be granted a license to continue wage differentials which were begun in the pre-Act period, as illustrated by the Mark and Mary example.

Up to this point many courts have been reluctant to give weight to statistics including persons hired prior to the actionable period. In Segar $v$. Smith, ${ }^{44}$ for example, the plaintiffs, a class of black agents at the federal Drug Enforcement Agency, alleged salary discrimination on the basis of race. They presented multiple regression statistics using education, prior federal experience, prior nonfederal experience, and race as explanatory factors. When they applied these factors to all agents present at the agency as of certain dates, the race coefficient was statistically significant at the .001 level. The plaintiffs also presented statistics including only agents hired after 1972. In so doing, their statistical significance dropped to the .05 level. The court stated: "Because the first regression measured disparities in the salaries of all black agents, including those hired before 1972, the race coefficient in that study may have reflected disparities resulting from the continuing effects of discrimination that occurred prior to 1972 , rather than actionable post -1972 discrimination." 45

By implication, the court indicates here that salary discrimination which has extended from before 1972 to the present is nonactionable. The Segar court admitted, however, that the second regression tended to understate the amount of post-1972 discrimination because it only measured discrimination among the newer agents. Those hired prior to 1972 could still suffer post1972 discrimination, and in fact are the very ones on whom discrimination is "most likely to operate" since they are contending for higher level positions and associated higher pay. ${ }^{46}$

The plaintiffs in Melani v. Board of Higher Education 47 similarly presented both complete statistics and a set limited to post-1972 hires. The court commented that this separate presentation was "to isolate those salary decisions made after Title VII became applicable to defendant on March 24, 1972."48 Again, one may argue that persons hired prior to 1972 were still subject to

(S.D.N.Y. 1983); Allen v. Prince George's County, 538 F. Supp. 833, 849 (D. Md. 1982), aff'd, 737 F.2d 1299 (4th Cir. 1984). But see Bazemore v. Friday, 106 S. Ct. 3000 (1986) (per curiam) (discussed infra pp. 95-98).

44. 738 F.2d 1249 (D.C. Cir. 1984), cert. denied, 471 U.S. 1115 (1985).

45. Id. at 1262 .

46. Id. at 1262-63; see infra p. 79 .

47. 561 F. Supp. 769 (S.D.N.Y. 1983).

48. Id. at 773 n.8. 
salary decisions made from 1972 to the present, and such salary decisions should be actionable.

In both Melani and Segar, the plaintiffs' statistical showing was strong enough to indicate statistically significant discrimination using the data limited to post-1972 hires, although in both cases this limitation reduced the degree of discrimination indicated. In Sobel v. Yeshiva University, ${ }^{49}$ however, the plaintiffs' statistics for post-1972 hires showed no significant discrimination, while statistics based on the entire set of pre- and post-1972 hires did indicate salary discrimination. ${ }^{50}$ The court cited with approval Gilinsky $v$. Columbia University, ${ }^{51}$ in which a federal district court had dismissed an action because the case was based largely on cumulative statistics and because "the probative value of pre-1972 statistics is at best minimal."52 The Sobel court dismissed the plaintiffs' claims of wage discrimination, in part because "the appearance of discrimination in salaries during the relevant time period resulted from lower salaries paid to female faculty members who had been hired prior to 1972." 53 In Allen $v$. Prince George's County, ${ }^{54}$ the court cited the plaintiff's multiple regression statistics as having "fatal flaws" because they did not exclude persons hired prior to $1972 .{ }^{55}$

The exclusion from the data set of all persons hired more than two years prior to the filing of an EEOC complaint is even more unreasonable than the exclusion of persons hired prior to 1972. These individuals include persons subjected to illegal discrimination after 1972 but who did not file any discrimination complaints. If the wages of all employees hired two years or more prior to the filing of an EEOC complaint are eliminated from the data set it may become impossible to demonstrate any discrimination because it takes longer than two years for many forms of discrimination to manifest themselves at any significant level. If it were not for the several-year delays in getting to court, the limitation of data to persons hired in the actionable period would preclude most evidence of discrimination. In any case, the exclusion of data on persons hired prior to the actionable period represents an unreasonable limitation on plaintiff's' ability to demonstrate present illegal discrimination.

\section{IV}

\section{Title Vil Theory as a Framework for Statistical Evaluation}

The analytical approach to statistically based cases has varied from court to court, but has often focused more on statistical methodology than on Title

49. 566 F. Supp. 1166 (S.D.N.Y. 1983), remanded, 797 F.2d 1478 (2d Cir. 1986); see infra note 126.

50. Id. at 1182 .

51. 488 F. Supp. 1309 (S.D.N.Y. 1980), aff'd, 652 F.2d 53 (2d Cir. 1981).

52. Sobel v. Yeshiva Univ., 566 F. Supp. 1166,1186 (S.D.N.Y. 1983).

53. Id.

54. 538 F. Supp. 833 (D. Md. 1982), aff'd, 737 F.2d 1299 (4th Cir. 1984)

55. Id. at 849 . Contrast Allen with the analysis in Bazemore v. Friday, 106 S. Ct. 3000 (1986) (per curiam) (discussed infra pp. 95-98). 
VII theory. Yet, in cases involving statistics as complex as multiple regression, it is particularly important to make sure that evaluation of the statistics presented is in keeping with the goals and policy of Title VII. The courts have developed an analytical structure under Title VII which includes rules for placing the burden of proof, deciding when inferences should be drawn, and deciding which party must bring forward evidence at each stage. These evidentiary issues are critical where competing statistical arguments are being made.

In addition, existing Title VII analysis includes a continuing violation theory that permits plaintiffs to reach events prior to the statutory time limits of Title VII where a pattern or series of related discriminatory events is involved. Both Title VII evidentiary theory and the continuing violation analysis can aid in the evaluation of statistically based wage discrimination claims.

\section{A. The Integrated Disparate Treatment/Impact Theory}

A promising approach to analyzing class-based Title VII cases involving multiple regression analysis uses disparate treatment and disparate impact theories in combination to address a particular claim of discrimination. This approach, which has only recently achieved explicit form in the District of Columbia Circuit's 1984 decision in Segar v. Smith, ${ }^{56}$ provides a structure for evaluating both the problem of factors claimed to have been missed in the regression equations and the problem of pre-1972 hires in the data set. The structure can aid the court in determining which party has the burden of presenting evidence on subissues within the litigation, and it also clarifies how defenses should be evaluated. Following an explanation of how the combined treatment/impact standard operates, it will be applied to the problems previously discussed.

In its June 4, 1984, decision in Segar $v$. Smith, ${ }^{57}$ the District of Columbia Circuit, after "plumb[ing] some of the deepest complexities of Title VII adjudication," 58 concluded that "plaintiffs' pattern or practice disparate treatment challenge to the employment system as a whole may also implicate disparate impact analysis." 59 In class-based cases, both disparate treatment and disparate impact analysis challenge a systemic pattern of discrimination. While the plaintiff's prima facie case is designed to demonstrate the disparate treatment of comparably qualified individuals, the employer may attempt to defend against the inference of discrimination shown by explaining that a specific neutral employment policy caused the differential treatment indicated. At this point, a court will have before it all the elements of a traditional disparate impact claim. Therefore, it is appropriate to require the

56. 738 F.2d 1249 (D.C. Cir. 1984), cert. denied, 471 U.S. 1115 (1985).

57. Id.

58. Id. at 1259 .

59. Id. at 1266. 
defendant to prove the business necessity of maintaining the "neutral" practice with the discriminatory effect.

The integrated disparate treatment/impact analysis proceeds as follows. First, to support a prima facie case, the plaintiff class must raise an inference of discriminatory treatment of class members, which is usually accomplished by offering statistics showing that members of the protected class are in a less favorable position than other comparably qualified persons. ${ }^{60}$ These statistics will generally be designed to show persuasive disparities, and will account for the major potential nondiscriminatory explanations for the disparities shown. By anticipating and discounting potential explanations, the plaintiffs' prima facie case assumes some elements of the pretext stage of the typical individual disparate treatment case. ${ }^{61}$ The statistical results must meet generally accepted standards for statistical significance, but " 'the appropriate degree of refinement of the plaintiffs' statistical analysis . . . may depend on the quality and control of the available data." "62 Where fine-tuned statistical techniques are used to evidence discriminatory treatment, "gross" disparities need not be shown. ${ }^{63}$

The defendant must bring forward evidence in rebuttal to the plaintiffs' prima facie case. Such a rebuttal can either attack the plaintiffs' showing that there is any disparity between the position of protected class members and others, or the rebuttal may be in the form of a legitimate nondiscriminatory explanation for the disparity observed. ${ }^{64}$

In order to challenge the existence of the disparity, the defendant may attack the methodology or significance of the plaintiffs' statistical presentation. Although not clarified by the Segar court, it is evident that not all methodological attacks relate to the "existence of the disparity" question. For example, a methodological attack relating to the sample size, functional form of the regression equation, or data tabulation procedures used, would focus primarily on the "existence of disparity" issue. A methodological attack based on the explanatory factors used in the regression would relate primarily to the nondiscriminatory explanation issue discussed below. The defendant's burden is measured by the strength of the plaintiffs' prima facie case. " 'The defendant's evidence must do more than merely raise an issue of fact . . . . It must cast sufficient doubt on the plaintiff's proof to cause the trier of fact to conclude that the plaintiff has not proved discrimination by a preponderance of the evidence." "65

The defendant may choose to defend itself by offering a legitimate nondiscriminatory explanation for the observed disparity-by explaining, for

60. Id. at 1267 .

61. Id. at 1274 .

62. Id. at 1276 (quoting Trout v. Lehman, 702 F.2d 1094 (D.C. Cir. 1983), vacated, 465 U.S. $1056(1984))$.

63. Segar, 738 F.2d at 1278 .

64. Id. at $1267-68$.

65. Id. at 1268 (quoting Vyanich v. Republic Nat'l Bank, 521 F. Supp. 656, 663 (N.D. Tex. 1981), vacated on other grounds, 723 F.2d 1195 (5th Cir. 1984)). 
example, that the plaintiffs have not accounted for an important job qualification. Unlike the typical Burdine sequence in which a mere articulation of a legitimate nondiscriminatory reason is sufficient for rebuttal, the Segar court held that the defendant's rebuttal in a class-based case must be "clear and reasonably specific," 66 and must be based on the presentation of sufficient evidence to permit the trier of fact to decline to draw the inference of discrimination from the plaintiffs' proof. ${ }^{67}$

In proposing a legitimate nondiscriminatory explanation for observed classwide disparities in treatment, the defendant may well rely on some specific employment policy, practice, or requirement which, although facially neutral, accounts for the disparate effect on the protected class. In so doing, the defendant has added the final necessary element for a disparate impact case. The plaintiffs' evidence of disparity and the defendant's evidence of a specific employment practice which is responsible for that disparity combine . to create the disparate impact issue.

Having offered such a business practice as an explanation for the disparate result, the defendant must proceed to defend the business practice as a job related business necessity, as required by Griggs v. Duke Power Co. ${ }^{68}$ The burden of proof in defending such a business practice is on the defendant. This burden is justified by the defendant's greater knowledge of its own business practices. While not addressed in the Segar opinion, presumably the plaintiffs, as in other disparate impact cases, may rebut the defendant's claim of business necessity by showing that a less discriminatory alternative exists which could serve the defendant's business purpose. ${ }^{69}$

Taking a discrimination case as a whole, "[w]hen the volleying is over ... a Title VII case is like all others: the trier of fact must weigh the plaintiff's proof and the defendant's rebuttal and decide whether the plaintiffs have met the ultimate burden of persuasion that the law imposes on them." 70 The proposed integrated disparate treatment/impact structure is admirably suited to address the succession of issues arising in statistically based cases.

1. Application of the Integrated Disparate Treatment/Impact Standard to the Issue of "Omitted Explanatory Factors". While not entirely necessary for its decision in Segar, the appellate court did indicate how its integrated disparate treatment/impact standard could apply in one instance where the defendants had alleged that the plaintiffs' multiple regression analyses had omitted an important explanatory factor. ${ }^{71}$

The plaintiffs presented a prima facie case relying on multiple regression analysis which accounted for several potential nondiscriminatory factors, but which still revealed significant discrimination. The defendants claimed that

66. Segar, 738 F.2d at 1268.

67. Id. at 1269 .

68. 401 U.S. 424 (1971).

69. Dothard v. Rawlinson, 433 U.S. 321, 329 (1977).

70. Segar, 738 F.2d at 1286.

71. Id. at $1287-88$. 
plaintiffs' regression analysis was flawed for failing to include "specialized experience" as an explanatory factor. The court rejected the defendants' claims, primarily because the factor was so vague and immeasurable that plaintiffs could not be faulted for not including it. Furthermore, since the factor was so subjective, it could possibly have served as a pretext for discrimination. Finally, since the defendants offered no statistics of their own to show that inclusion of the factor would account for the discrimination shown, the defendants' rebuttal simply did not, as a matter of law, rise to the level necessary to defeat plaintiffs' prima facie case.

In addition, the court pointed out that if the defendants had rebutted the plaintiffs' prima facie case by making a credible showing that the factor really stood for "prior law enforcement experience," and that such a factor explained the salary disparity shown, then the defendants would have done no more than create a disparate impact case. In effect, the defendants would have shown that the prior law enforcement experience requirement was a facially neutral employment practice with a disparate negative impact on blacks. The defendants would then have had to justify such a requirement by proof of job relatedness.

While the portion of the Segar court's opinion which deals with the application of disparate impact theory in the "omitted factor" context is actually dicta, the logic of the proposed application is compelling. This framework could be applied to any omitted factor attack on the plaintiffs' multiple regression analyses. For example, if an employer claimed that "engineering experience" was a crucial variable omitted from the plaintiffs" regressions, the defendant would first have to show through its own statistics that inclusion of the engineering factor accounted for the discrimination previously shown. In so doing, the employer would have indicated that engineering experience is a facially neutral factor with a disparate negative effect on the plaintiff class. The defendant would then have the burden of proving the business necessity of using engineering experience as a factor affecting salary rates. In a set of technical jobs, the employer may well be able to justify the legitimate business purpose of rewarding engineering experience. In a set of jobs where engineering experience had little or no relevance, the employer obviously could not show business necessity. Either way, an orderly series of inquiries serves to isolate the dispositive issues.

The integrated disparate treatment/impact approach should facilitate even the most difficult omitted factor issues, such as the claim that "job level" should have been included in a plaintiff's regression analysis. Courts have reached different decisions on this issue. ${ }^{72}$ Although they have relied on precedent from prior decisions, the focus should be on the facts of the individual case. The proposed framework would help focus such as inquiry. First, the defendant would have to demonstrate that the inclusion of a "job

72. See, e.g., EEOC v. International Business Machs. Corp., 583 F. Supp. 875, 906 (D. Md. 1984) (court critical of plaintiff's statistics because “job level" not included); Craik v. Minnesota State Univ. Bd., 731 F.2d 465, 475 (8th Cir. 1984) (court found "rank" not a valid explanatory factor). 
level" factor would account for the discrimination inferred by the plaintiff's statistics. As a neutral factor with disparate impact on salary, job level would have to be justified by the defendant as a business necessity for salary setting. If the defendant merely claimed that job level was a "convenient" basis for setting salaries, such justification might not rise to the level of "proof of business necessity." In any case, the plaintiff could attempt to show that other, less discriminatory measures of the value of an employee exist which could serve the employer's salary setting needs, such as education, experience, and quality of performance. If "job level" is a measure of the value of an employee, the employer would be in the best position to evaluate that measure. Finally, if in the course of the class-based lawsuit, the plaintiff also proved discrimination in promotions, then the employer could not even point to job level as a legitimate nondiscriminatory explanation. Job level itself would be a product of promotion discrimination, and a pretext for salary discrimination.

In cases where the alleged omitted factor is a potentially subjective factor such as performance evaluation score, the proposed standard places the burden on the defendant to demonstrate that the performance evaluation system is legitimately job related. The defendant, claiming that performance evaluations are neutral, can present evidence on the validity and objectivity of the evaluation process. If the employer can prove the system is job related, then the omitted factor provides a legitimate explanation for the discrimination that otherwise would be inferred.

2. The Application of the Integrated Disparate Treatment/Impact Standard to the Issue of Prestatutory Hires in the Data Set. As discussed previously, ${ }^{73}$ defendants frequently attack plaintiffs' multiple regression analyses as having been skewed by data pertaining to persons hired prior to 1972 or prior to the actionable reach of Title VII. While the Segar court did not apply the integrated disparate treatment/impact framework to this question, it is certainly an appropriate issue for the analytical framework.

Once again, for example, a plaintiff class may raise an inference of wage discrimination using regression statistics, based on a data set pertaining to all employees in a set of jobs, including both pre- and post-1972 hires. The defendant, in rebuttal, may propose a legitimate nondiscriminatory explanation for the apparent wage disparity: it is merely the result of the effects of nonactionable discrimination which took place prior to 1972. Under the analytical structure proposed in Segar, mere articulation of this explanation is not sufficient. ${ }^{74}$ The defendant must demonstrate that if the effect of pre-1972 discrimination is accounted for, the statistical showing of discrimination will be eliminated. This process results in some interesting consequences.

73. See supra section III; see also Bazemore v. Friday, 106 S. Ct. 3000 (1986) (per curiam) (discussed infra pp. 95-98).

74. Segar, 738 F.2d at 1269. 
First, the defendant must prove the existence and extent of pre-Act discrimination to prove that it was a factor affecting post-1972 statistics. ${ }^{75}$ This places the defendant in what could be an embarrassing dilemma. The defendant must admit to pre-Act discrimination, which if not illegal, is not now something to advertise. This admission may be particularly embarrassing for discrimination which occurred after Title VII went into effect, but prior to the statute of limitations period on the particular case. Such discrimination was illegal; the employer merely did not get caught.

Second, by admitting to pre-Act discrimination, a defendant sets itself up for the plaintiff's claim that if its personnel policies have remained basically unchanged, then this discrimination has persisted into the actionable period as a continuing violation. ${ }^{76}$ This admission is especially dangerous for the defendant where pre-statute of limitations period discrimination is involved. While it is possible that an employer stopped discriminating in 1972 due to the passage of the Title VII Amendments, which made it illegal to discriminate, it is not plausible that an employer stopped discriminating on September 2, 1981, or whatever other random date falls two years prior to the date the EEOC charge was filed. Since the employer did not know then that a charge would be filed two years later, the date would have had no significance at the time.

Finally, measurement of the extent of pre-1972 discrimination (so that it could be factored out of present discrimination) would require a defendant to do a multiple regression analysis on pre-1972 wages for men and women to see what value the sex factor had at that time. In order not to make the pre1972 sex factor artificially small, the defendants would have to choose their explanatory factors in an unbiased manner. If they could then prove, for example, that $\$ 300$ worth of the present wage gap was the effect of pre-Act discrimination, they could argue for subtracting it from the $\$ 350$ wage gap evident in post-1972 statistics on pre-1972 hires. But the explanatory factors the defendants used for the pre-1972 regression would essentially be an admission that such factors were valid to measure wage rates to reveal post1972 discrimination, absent a drastic change in personnel policies. Alternatively, plaintiffs could rebut the defendants' claims that pre-Act discrimination had an effect on post-1972 results by using the defendants' proposed post-1972 explanatory factors on pre-1972 wage rates. If the defendants claimed they did discriminate prior to 1972 and such discrimination was not revealed using the defendants own proposed post1972 factors, then the credibility of the factors the defendants proposed for the purpose of rebutting the inference of discrimination in the actionable period would be greatly diminished.

Presuming the defendants could measure, and therefore factor out, the relationship of present wage rates to pre-1972 wage discrimination, the defendants would be able to demonstrate, in effect, that pre-1972

75. See id. at 1281 .

76. See infra section IV B. 
discrimination is a facially neutral factor with a disparate negative impact on the protected group. Under the treatment/impact framework, the defendant would then be obliged to prove the business necessity of relying in part on pre-1972 discrimination to set present wage rates.

It is highly unlikely that there is any way to prove the business necessity of such a practice. Wages which are based partly on pre-1972 discrimination can never be shown to be as equally job related as wages based entirely on objective qualifications. Any wage system based on qualifications and not on pre-Act discrimination will be a less discriminatory alternative to a wage system based in part on pre-Act discrimination. Thus, under the integrated disparate treatment/impact analytical framework, it is clear that a present reliance on pre-1972 discrimination constitutes present illegal discrimination which should be remediable under Title VII.

\section{B. The Continuing Violation Theory}

The primary analytical argument which has been used to support the exclusion of data from prestatutory hires in the multiple regression data set has been that these data include the "effects" of pre-Act discrimination which is not remediable under Title VII. ${ }^{77}$ The courts appear to be in agreement that the present effects of pre-Act discrimination are not actionable, ${ }^{78}$ but present discrimination that is part of a continuing pattern of discrimination which began prior to 1972 is actionable. Such discrimination is referred to as a "continuing violation."79 The continuing violation theory has been largely ignored in wage discrimination cases based on multiple regression analysis, but the approach is admirably suited to address the persistent excuse of nonactionable, pre-Act discrimination.

The leading case on the issue of continuing effects of discrimination is United Air Lines, Inc. $v$. Evans. ${ }^{80}$ In Evans, a stewardess was terminated under United's nonmarriage policy. Several years later, after the policy was determined to be illegal and had been abandoned, the stewardess reapplied and was rehired. However, she was granted no seniority based on her prior work for United. The Supreme Court held that there had been no violation of Title VII because anyone, male or female, who left United's employment and then came back lost all prior accrued seniority. ${ }^{81}$ The court rejected the plaintiff's claim of continuing discrimination because her challenge to the policy under which she was terminated was untimely. The termination therefore, had no legal significance as an illegal event, and she could prove no present violation. ${ }^{82}$

77. See supra section III B.

78. See, e.g., Bazemore v.Friday, 106 S. Ct. 3000 (1986) (per curiam) (discussed infra pp. 95-98); Trout v. Lehman, 702 F.2d 1094, 1104 (D.C. Cir. 1983), vacated, 465 U.S. 1056 (1984).

79. See Milton v. Weinberger, 645 F.2d 1070, 1074-77 (D.C. Cir. 1980).

80. 431 U.S. 553 (1977). Contrast Evans with Bazemore v. Friday, 106 S. Ct. 3000 (1986) (per curiam) (discussed infra) pp. 95-98.

81. Id. at 557 .

82. Id. at 558 . 
The Evans case has been interpreted as defeating the theory that a continuing effect of past discrimination is presently actionable. ${ }^{83}$ Nonetheless, many courts have sought to narrow this interpretation, and have upheld the concept that a continuing pattern of discrimination from prior to 1972, or prior to the two year back pay limitation of Title VII, is still actionable.

In Milton v. Weinberger, ${ }^{84}$ the District of Columbia Circuit set out criteria for determining a continuing violation of Title VII. Such a violation consists of " 'a series of related acts, one or more of which falls within the limitations period, or the maintenance of a discriminatory system both before and during the statutory period." "85 The discrimination "may not be 'limited to isolated incidents, but must pervade a series or pattern of events which continue to within' the filing period." 86

In the Mark and Mary example set out in Section III, ${ }^{87}$ both employees were equally qualified, but Mary was discriminatorily underpaid by $\$ 300$ when she was hired, prior to 1972 , and the wage gap persisted into the actionable period. In that example, and in the many actual cases like it, it seems only fair to consider the discrimination to be continuing. There is current discrimination since Mary is treated less favorably every month she is paid $\$ 300$ less than Mark. The employer could have adjusted this difference at any time but did not do so, to its own financial benefit. The case clearly falls within the generally accepted criteria for continuing violation since the yearto-year salary setting is a series of related acts which are part of a discriminatory system that began prior to and extended into the statutory period. The facially neutral system of granting $\$ 100$ raises per year to both Mary and Mark operates to maintain the perpetual $\$ 300$ wage gap.

If there is a reasonable distinction to be drawn between "perpetuating the effects of pre-Act discrimination" and "continuing violations" in the compensation context, perhaps it can be demonstrated by the following example:

In 1970, Jane and Jim apply for similar jobs with Employer. Employer has a policy of not hiring women so he only hires Jim. All employees start at $\$ 1,000$ per month and receive a $\$ 100$ raise each year. In 1972 , Title VII makes discrimination illegal. Jane applies again and is hired. In 1974, Jim's salary is $\$ 1,400$ per month, while Jane's salary is only $\$ 1,200$ per month. The $\$ 200$ wage gap is a continuing effect of pre-1972 discrimination. In this instance the employer uses a neutral policy of basing all salaries on $\$ 1,000$

83. Courts have relied on the Supreme Court's statement in Evans that "[r]espondent is correct in pointing out that the seniority system gives present effect to a past act of discrimination. But United was entitled to treat that past act as lawful after respondent failed to file a charge of discrimination." Id. at 559 .

84. 645 F.2d 1070 (D.C. Cir. 1980).

85. Id. at 1075 (quoting B. Schlei \& P. Grossman, Employment Discrimination Law 232 (Supp. 1979)).

86. Milton, 645 F.2d at 1076 (quoting Laffey v. Northwest Airlines, Inc., 567 F.2d 429, 473 (D.C. Cir. 1976), cert. denied, 434 U.S. 1086 (1978)).

87. See supra section III B. For a similar fact situation, see Bazemore v. Friday, 106 S. Ct. 3000 (1986) (per curiam) (discussed infra pp. 95-98). 
plus an additional $\$ 100$ for each year of service. This neutral policy is job related because each additional year of service presumably makes an employee worth $\$ 100$ more to the employer. It is true that but for the pre-Act discrimination, Jane would have two more years of service-but the pre-Act discrimination was not illegal. Jane is now being paid the same as any man who began work in 1972 when she did. Her value to her employer is only based on two years of service, and she is being paid what she is worth. Thus, there is no present discrimination. This model is analogous to the facts of Evans.

In the Mark and Mary example, Mary is not now being paid the same as a man who began work at the same time she did. Her present value to the employer is exactly the same as Mark's since they are similarly situated in terms of qualifications and experience. Paying Mary less than Mark now should, therefore, be viewed as a continuing violation, not just the "effect" of a pre-1972 act.

Defendants frequently raise the argument that pre-Act factors are entirely responsible for present wage discrimination. Such a defense presents employers as mere pawns in the hands of their own personnel policies, unable to change what was begun years before. Plaintiffs must directly confront this rationale so that courts are not blinded by seemingly discrimination-free statistics which have been purged of all data on persons hired prior to 1972, or of all data on persons hired prior to two years before the complaint was filed.

Since members of the plaintiff class who were hired prior to the actionable period may well have a valid continuing violation claim, the plaintiff class should not have to limit itself to presenting statistics on individuals hired during the actionable period. In our Mark and Mary example, even if the employer stopped his practice of starting male employees at a higher wage than comparably qualified female employees in 1972, a look at post-1972 hires only will reveal no discrimination at all, yet females hired prior to 1972 are still suffering discrimination with respect to the pre-1972 male hires. To detect this discrimination, it is necessary to look at data that include pre-1972 hires.

In Sobel v. Yeshiva University, ${ }^{88}$ the court was critical of plaintiffs' statistical presentation, which included data on pre-1972 hires. The court, quoting from Gilinsky v. Columbia University, ${ }^{89}$ stated that " "the probative value of pre1972 statistics is at best minimal." "90 Applying the terminology of "pre-1972 statistics" to post-1972 data on present salaries, including persons hired prior to 1972 , could lead to substantive errors in analysis.

88. 566 F. Supp. 1166 (S.D.N.Y. 1983), rev'd per curiam, 797 F.2d 1478 (2d Cir. 1986). In Sobel, the Second Circuit remanded the case to the district court in light of Bazemore v. Friday, $106 \mathrm{~S}$. Ct. 3000 (1986) (per curiam), to consider the significance of pre-Act discrimination and the evidentiary weight to be afforded multiple regression analysis. Sobel, 797 F.2d at 1479.

89. 488 F. Supp. 1309 (S.D.N.Y. 1983).

90. Sobel v. Yeshiva Univ., 566 F. Supp. 1166, 1182 (S.D.N.Y. 1983), rev d per curiam, 797 F.2d 1478 (2d Cir. 1986). 
Perhaps the confusion between "pre-1972 statistics" and multiple regression statistics including individuals hired prior to 1972 indicates some misunderstanding of how multiple regression analysis works. As used to model salary setting, multiple regression does not cumulate data taken at different periods of time. To show discrimination in salaries for 1974, 1975, and 1976, for example, one must run three separate regressions. Each one includes only salaries paid in the particular year in question. Graphically, multiple regression methodology is analogous to Table 3 , which shows the present salary of a class of individuals, not Table 2 , which merely shows the salary progression, over time, of two people. While Table 2 obviously contains pre-1972 data, Table 3 does not.

\section{Salary Overtime}

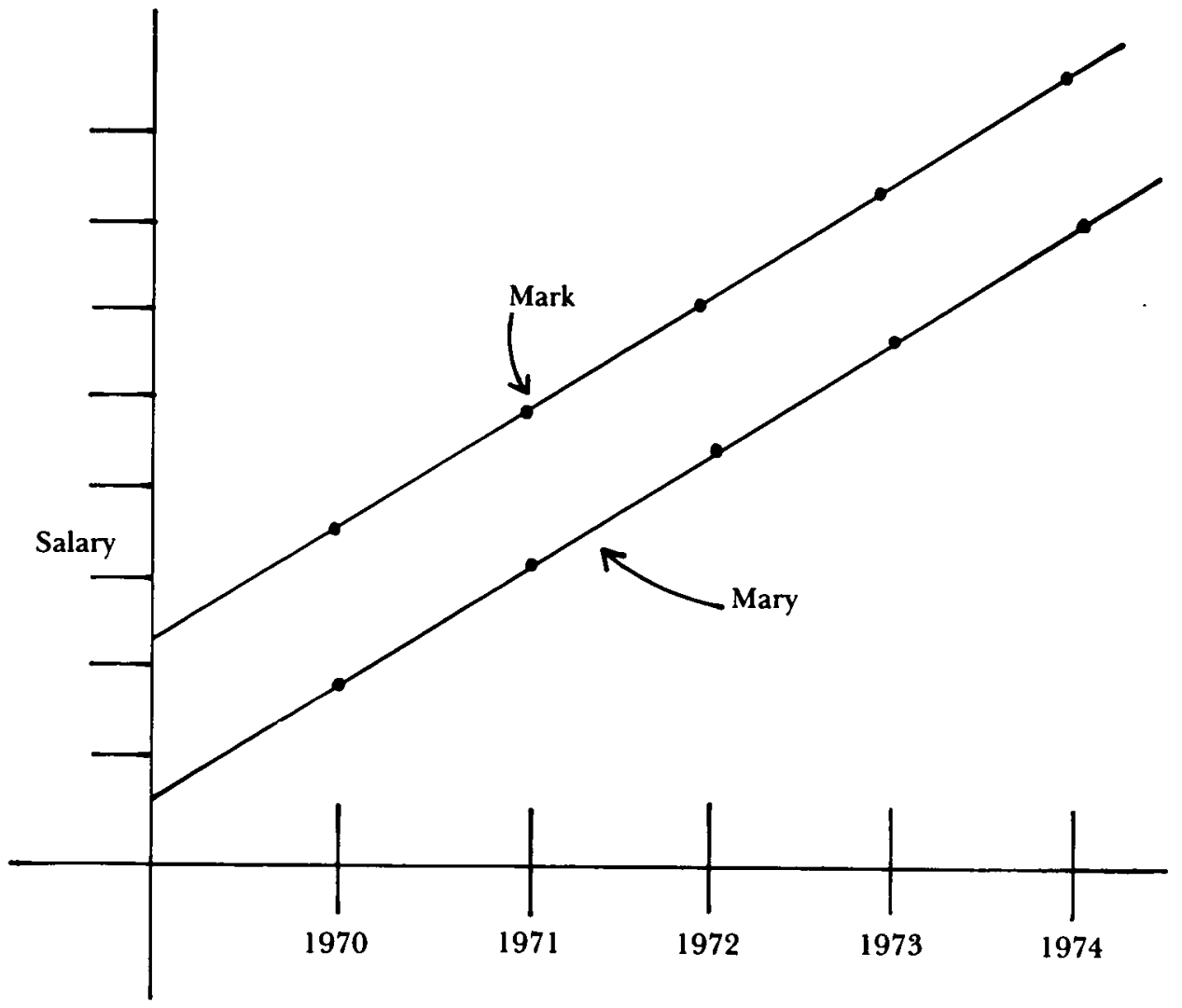




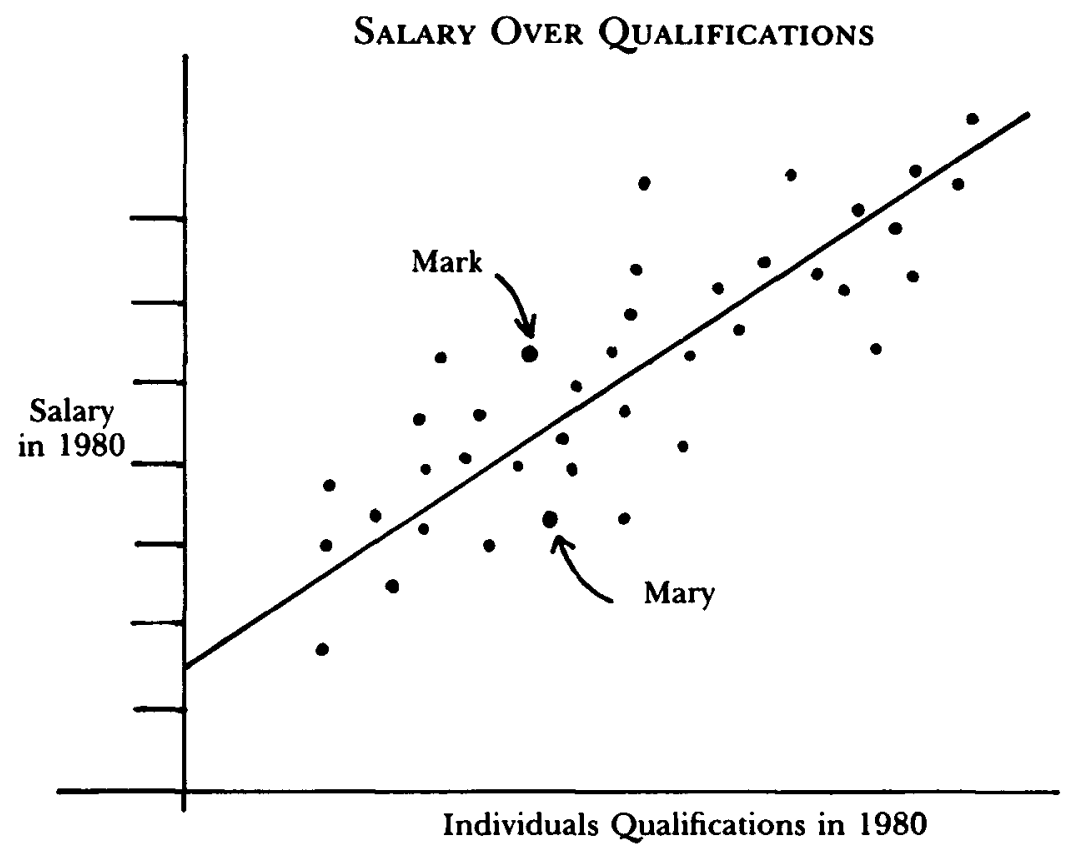

The Sobel court's language could lead to confusion between pre-1972 statistics and data on pre-1972 hires. The statistics presented by the plaintiffs in Sobel were based on salaries for the relevant years 1974 through 1979, and thus they were not pre-1972 statistics. They happened to include the 1974 to 1979 salaries of persons hired prior to 1972 . They revealed that the employer was, in the relevant time period, paying women less than comparably qualified men. ${ }^{91}$ Again, an employer's pre-1972 discrimination should not provide it with license to discriminate indefinitely. Although the employees hired before 1972 are probably barred from collecting the additional wages they should have been paid in the pre-1972 period, they should not be barred from collecting additional wages discriminatorily withheld from 1974 through 1979, when Title VII was in full effect.

The Sobel court's quote on "pre-1972 statistics" from Gilinsky was misplaced. Gilinsky was a hiring discrimination case. There, the plaintiffs attempted to prove discrimination by showing that a university had an extremely low percentage of women on the faculty. Most people on the faculty, however, were hired prior to 1972. Among post-1972 hires, women were equitably represented. Therefore, statistics on pre-1972 hiring decisions were largely irrelevant in the context of a post-1972 hiring discrimination case.

In Valentino $v$. United States Postal Service, ${ }^{92}$ a case including a discrimination claim based on multiple regression analysis, the plaintiff actually attempted to

91. The Sobel court found the plaintiff's statistics to be unpersuasive for other reasons as well, however. Id. at 1178-82.

92. 674 F.2d 56 (D.C. Cir. 1982). 
invoke the continuing violation theory. The approach was rejected in the District of Columbia Circuit's 1982 opinion, but only because the continuing violation theory did not fit the particular circumstances of the case. ${ }^{93}$ Due to the Title VII limitations period, based on the filing date of the complaint, only post-1976 discrimination was normally actionable in the case. The plaintiff wanted to use the continuing violation theory to reach the 1974 to 1976 period. The employer, however, had instituted a totally new promotion system in 1976: post-1976 employment decisions were not part of a continuing pattern or system of discrimination extending from the prestatutory period. Additionally, the court questioned the plaintiff's qualifications to represent the class of persons discriminated against prior to 1976. On the facts, the continuing violation theory simply did not apply. It therefore could not be used to defeat the criticism made at the trial court level, that plaintiff's statistics failed to factor out the effects of prestatutory discrimination. ${ }^{94}$

The issue of data on pre-1972 hires was a central feature of the recent series of decisions culminating in the Supreme Court case of Lehman $v$. Trout. ${ }^{95}$ If not carefully read, these cases could be wrongly interpreted as giving Supreme Court approval to the concept that wage discrimination that has extended from prior to the actionable period is not now actionable. In fact, the Trout decisions left open the question of whether a continuing violation theory might be applied in wage discrimination cases if evidenced by multiple regression analysis.

The Trout case was originally tried in the District of Columbia District Court in 1981 under the name Trout $v$. Hidalgo. ${ }^{96}$ In his district court opinion, Judge Harold Green did not specifically address the continuing violation theory, but he appeared to embrace some of its assumptions. The plaintiffs presented multiple regression analyses of the salaries of the professional employees at a naval computer operations center. Along with education and experience factors, sex proved to be a statistically significant explanatory factor affecting salary rates. Women were paid $\$ 2,200$ to $\$ 3,500$ per year less than comparably qualified males. The plaintiffs' data base included salaries during the period from 1972 through 1979 of employees hired both before and after Title VII became applicable to the government in 1972.

While the court stated that "discriminatory conduct which occurred solely prior to March 24, 1972, is not directly actionable," 97 it noted that "[i]t is likely that ... discrimination before 1972, even if coupled with neutral

93. Id. at 65 .

94. Valentino v. United States Postal Serv., 511 F. Supp. 917 , 955 (D.D.C. 1981), aff'd, 674 F.2d 56 (D.C. Cir. 1982).

95. Trout v. Hidalgo, 517 F. Supp. 873 (D.D.C. 1981), aff'd in part, rev'd in part, vacated in part sub nom. Trout v. Lehman, 702 F.2d 1094 (D.C. Cir. 1983), vacated, 465 U.S. 1056 (1984).

96. Id.

97. Id. at $879-80$. 
employment practices since then, produced actionable continuing discriminatory effects after 1972." 98 The court found the situation

analogous to the effect of racial discrimination by labor unions that is succeeded by use of neutral seniority rules, or of discriminatory voting registration practices followed by neutral, but particularly arduous, requirements. In such cases, courts have not hesitated to hold that "freezing" the effects of prior discrimination is actionable. ${ }^{99}$

The court indicated that disparities in grade level, and thus salary, which remained over several years could be attributed to the employer because over time such disparities would tend to demonstrate inequitable promotion practices. If women failed to catch up to their proper grade level, it could have been due to promotion regulations which "locked in the effects of the earlier discrimination." 100

On appeal to the District of Columbia Circuit, the government employer argued that plaintiffs' regression statistics failed to make out a prima facie case because they ignored the time limitations embodied in Title VII. Judge Harry Edwards noted that "absent a valid claim of a continuing violation,"101 Title VII does not apply to pre-1972 discrimination by the government. Reviewing the lower court holding he stated:

The District Court concluded that plaintiffs need not factor out time-barred discrimination because defendants may be held liable for the continuing effects of that discrimination. This theory was once in vogue, but is flatly inconsistent with the Supreme Court's pronouncements in Hazelwood School District v. United States and United Air Lines, Inc. v. Evans. ${ }^{102}$

There are several analytical problems presented here, arising from procedure, theory, and semantics. With respect to procedure, the District of Columbia Circuit explicitly stated in Milton $v$. Weinberger ${ }^{103}$ that a plaintiff wishing to make use of the continuing violation theory must address the issue at the trial stage. ${ }^{104}$ It cannot be raised for the first time on appeal. If the Trout plaintiffs did not specifically raise the issue in the district court, the theory was probably deemed waived by the appellate court, despite the district court's comment regarding the "continuing discriminatory effects." 105 Judge Edwards' reference to the absence of a "valid claim of continuing violation" simply indicates that in that case such a claim had not been raised.

With respect to theory, the Hazelwood School District $v$. United States 106 and United Air Lines, Inc. $v$. Evans ${ }^{107}$ cases are not precisely on point. Neither of those cases eliminated the continuing violation theory. The Hazelwood case

98. Id. at 880 .

99. Id. at 880 n. 19 .

100. Id. at 885 .

101. Trout v. Lehman, 702 F.2d at 1104

102. Id. (citations omitted). Contrast these cases with Bazemore v. Friday, $106 \mathrm{~S}$. Ct. 3000 (1986)

(per curiam) (discussed infra) pp. 95-98.

103. 645 F.2d 1070 (D.C. Cir. 1980).

104. Id. at 1077 .

105. Trout v. Hidalgo, 517 F. Supp. at 880 .

106. 433 U.S. 299 (1977).

107. 431 U.S. 553 (1977). 
was yet another hiring discrimination case in which the plaintiffs attempted to show discrimination in the period from 1972 through 1974 by showing that less than two percent of the teachers working at the school district at that time were black. This is a classic example of the effect of pre-Act discrimination. The court pointed out that statistics showing the school district's post-Act hiring might rebut the inference of discrimination. Obviously, even if the district hired its new teachers without discrimination, the district-wide proportion of black teachers would remain low in the immediate post-Act period. An employer who, after 1972, "made all its employment decisions in a wholly nondiscriminatory way would not violate Title VII even if it had formerly maintained an all-white work force." 108 A "wholly nondiscriminatory way" is not the same as a wholly neutral way, for as Griggs v. Duke Power Co. ${ }^{109}$ teaches, even neutral policies may have a discriminatory impact, and may be challenged on that basis. The district court in Trout evidently did not view the employer's post-Act practices as wholly nondiscriminatory. The statistical rationale of Hazelwood simply does not apply to the Trout facts.

With respect to semantics, the Trout district court did speak of the "continuing discriminatory effects," 110 "freezing the effects," 111 and "locking in the effects" 112 of prior discrimination. This language, particularly the key word, "effects," is the very language that was used to express the now rejected "perpetuating the effects of pre-Act discrimination" theory. ${ }^{113}$ Whether the district court used this language intentionally, or merely failed to heed the semantical differences between "continuing discriminatory effects" and "continuing violation," the court's word choice identified its opinion as embracing the now unpopular "continuing effects" theory.

The Supreme Court granted certiorari, but in a summary disposition of the case, reflected in a brief memorandum opinion, simply remanded the case to the court of appeals to be remanded back to the district court for a determination of "what evidentiary value respondents' and petitioners' statistical evidence has in light of the court of appeals' conclusions of law concerning employment decisions that are not actionable in this case." 114 The Supreme Court was apparently concerned that the appellate court had found facts which should have been found in the first instance by the district court. The Supreme Court did not review the record in the case and, according to a dissenting opinion by Justices Stevens, Marshall, and Brennan, merely second-guessed the judgment of the appellate court "after the most

108. Hazelwood, 433 U.S. at 309.

109. 401 U.S. 424 (1971).

110. Trout v. Hidalgo, 517 F. Supp. at 880 .

111. Id. at 880 n. 19 .

112. Id. at 885 .

113. See United Air Lines, Inc. v. Evans, 431 U.S. 553 (1977). But see Bazemore v. Friday, 106 S. Ct. 3000 (1986) (per curiam).

114. Lehman v. Trout, 465 U.S. at 1056. 
truncated of presentations." 115 The dissenters believed the appellate court did not improperly find facts, but rather relied on facts already cited by the district court. ${ }^{116}$

Clearly, the Supreme Court reached no considered opinion as to which employment decisions were "not actionable in this case," 117 although the dissenters indicated that they included "pre-1972 discrimination." 118 The majority's memorandum opinion thus did not address whether the post-1972 disparities in grade level of pre-1972 hires were actionable or not. The minority, who commented on the case at some length, stated that "the evidence concerning the actions of [the government employer] alone still demonstrated the existence of unlawful discrimination . . . [ [D]uring the post-Act period, female employees were paid consistently less than male employees even when the factors used by the Civil Service Commission to make placement decisions were considered." 119 The three dissenting Justices cited the district court's determination that "disparities in grade level remaining over several years could still be properly attributable to [the government]" 120 and that, in such case, the failure to "promote equitably individuals who were discriminated against at hiring . . . would constitute direct discrimination."121 In summary, it appears that at least these three Justices could find present discrimination in a case where pre-Act discriminatory treatment continued into the post-Act period.

In the recent Segar $v$. Smith ${ }^{122}$ decision, the District of Columbia Circuit stepped carefully around the issue of pre-1972 hires in the data set, in light of the Supreme Court's remand of Trout relating to the evidentiary value of nonactionable employment decisions. The Segar court did not find it necessary to exclude pre-1972 hires from the data set because at trial the defendants had provided no evidence that doing so would alter the inference of discrimination shown by plaintiffs' statistics. The defendants could not show that pre-1972 discrimination "affected" the post-1972 figures because the defendants neither admitted nor proved that they discriminated against blacks prior to 1972.123 The Segar court did hold that the district court would have erred had it concluded that disparities resulting from the continuing effects of pre-1972 discrimination were actionable. In a footnote, however, the appellate court indicated that it was a correct statement of the law that continuing effects of pre-1972 discrimination are actionable under a continuing violation theory. ${ }^{124}$ The court further noted that it did not think the record supported a continuing violation finding under the Segar facts, but

115. Id. at 1062 (Stevens, J., dissenting).

116. Id. at 1057-58 (Stevens, J., dissenting).

117. Id. at 1056.

118. Id. at 1057 (Stevens, J., dissenting).

119. Id. at 1060 (Stevens, J., dissenting).

120. Id. at 1060 n.6 (Stevens, J., dissenting).

121. Id. (Stevens, J., dissenting).

122. 738 F.2d 1249 (D.C. Cir. 1984), cert. denied, 105 U.S. 2357 (1985).

123. Id. at $1281 \mathrm{n} .23$.

124. Id. at 1281 n.22. 
it did not indicate why not. Since neither was pre-1972 discrimination admitted or proved, nor was an effort ever made to prove a continuing pattern of discrimination, there are obvious reasons why the record could have been insufficient to support a continuing violation theory. The Segar court clearly did not exclude the potential use of the continuing violation theory in all statistically based wage discrimination cases.

In fact, in the damages section of the Segar decision, the court of appeals concluded that the record contained insufficient facts to measure back pay because it could not determine whether all of the plaintiffs' regression race coefficients measured post-1972 discrimination. The court stated: "It may ... be that the portion of the disparity that reflects continuing effects of pre1972 discrimination might be actionable on a continuing violation theory." 125 Therefore, the case was remanded to the trial court to determine if a continuing violation had occurred or if there had been nonactionable continuing effects. Back pay was to be computed accordingly. In this discussion, the court of appeals clearly opened the door to the potential use of the continuing violation theory in future multiple regression based wage discrimination claims. When used in combination with the integrated disparate treatment/impact analytical structure, the continuing violation theory provides plaintiffs with a powerful approach to addressing persistent and pervasive wage discrimination problems.

\section{ConClusion}

Multiple regression analysis provides plaintiffs with a sophisticated and powerful evidentiary tool for detecting even subtle forms of discrimination. The evidence provided by such a statistical technique is only persuasive, however, if the methodology behind the numbers is credible.

This article has presented two analytical approaches which provide a framework for assessment of statistical credibility. These approaches, the integrated disparate treatment/impact theory and the continuing violation theory, are particularly useful in evaluating typical questions as to omitted variables and prestatutory influences on the data set. As the analytical approach used in cases based on multiple regression analysis rises to the level of sophistication required by the evidentiary method, the full potential of multiple regression techniques to alleviate hidden forms of discrimination should be realized.

\section{POSTSCRIPT}

This article was prepared for a symposium in the fall of 1984 . Since that time, a number of federal courts have considered multiple regression statistics

125. Id. at 1292 . 
in the context of discrimination cases. ${ }^{126}$ Most notably, in the recent case of Bazemore $v$. Friday, ${ }^{127}$ the United States Supreme Court addressed two of the central issues discussed in this article: missing factors and pre-Act discrimination.

The Bazemore case involved claims of race-based wage discrimination among the employees of the North Carolina Agricultural Extension Service (Extension Service), which is operated as a division of North Carolina State University. Prior to August, 1965, the Extension Service was divided into a white branch and a "Negro branch."128 The salaries of the employees in the white branch were generally higher than the salaries of the employees in the Negro branch. After Title VII became effective, the two branches were merged but wage disparities continued. ${ }^{129}$

126. See, e.g., Bazemore v. Friday, 106 S. Ct. 3000 (1986) (per curiam), aff'g in part, vacating in part, 751 F.2d 662 (4th Cir. 1984). Bazemore is discussed infra at text accompanying notes 127-45. For a similar analysis, see Hanson v. Veterans Admin., 800 F.2d 1381, 1389 (5th Cir. 1986), which upheld the district court's criticism of plaintiffs' regression analysis in a housing discrimination case because of plaintiffs' failure to include factors such as the crime rate and school quality in the regression equation to predict property appraisal value. For another example, see Sobel v. Yeshiva Univ., 797 F.2d 1478, 1478 (2d Cir. 1986), which remanded the district court's decision (discussed supra at text accompanying notes 88-90), for reconsideration of effects of pre-Act discrimination and missing factors in regression, in light of Bazemore. Additionally, see Griffin v. Board of Regents, 795 F.2d 1281 , 1289-90 (7th Cir. 1986), which, one month before the Bazemore decision, upheld the district court's rejection of plaintiff female teachers' statistics because they failed to factor out the effects of pre-1972 decisions and did not control for possession of a doctorate degree. For a contrasting view, see Lewis v. Bloomsburg Mills, Inc., 773 F.2d 561 (4th Cir. 1985), which reversed and remanded the district court's rejection of plaintiffs' multiple regression statistics. In Lewis, the circuit court found that the mere failure of plaintiffs' statistical analysis to rule out every conceivable non-discriminatory factor as an explanation for the observed wage disparity, insufficient to reject the statistics. Id. at 575. The court pointed out that the defendant failed to demonstrate that any additional factor worked into the regression analysis would reduce the apparent discrimination. Id. Notably, this decision was written by Judge Phillips, who wrote the dissent in the Fourth Circuit's Bazemore decision, 751 F.2d at 688 (Phillips, J., dissenting in part), discussed infra text accompanying notes 133-42. For another example of a court approval of plaintiff's statistics, see EEOC v. McCarthy, 768 F.2d 1, 3 (1st Cir. 1985) (upholding the district court's reliance on statistical evidence in a wage discrimination case including data for years prior to the actionable reach of the Equal Pay Act, 29 U.S.C. $\$ 206$ (d) (1975). The court stated: "a decision to hire an individual at a discriminatory low salary can, upon payment of each subsequent paycheck, continue to violate the employee's rights." 768 F.2d at 3 (quoting Lamphere v. Brown Univ., 685 F.2d 743, 747 (1st Cir. 1982)). For a related view, see Ende v. Board of Regents, 757 F.2d 176, 182-83 (7th Cir. 1985), which upheld a voluntary pay equity adjustment scheme based on a regression type methodology. In Ende, the university's pay equity adjustment scheme was challenged by male faculty members as a violation of the Equal Pay Act of 1963, 29 U.S.C. $\$ 206$ (d) (1982). 757 F.2d at 179. The university had employed a regressiontype methodology to dole out pay increases for female faculty members, based on objective factors. Subsequently, multiple regression analysis indicated that a sex-based wage disparity favoring males had existed prior to the introduction of the pay equity adjustment scheme. Id. at 180. For a discussion of statistical methodology, the probative value of statistical evidence, and burdens of proof, see Coates v. Johnson \& Johnson, 756 F.2d 524, 539, 548 ( 7 th Cir. 1985), which upheld the district court's conclusion that plaintiffs' statistical evidence was not probative because of the failure to include employees' disciplinary records, and other methodological problems. The Coates court would place the burden of persuasion on the plaintiff to show that an alleged explanatory factor used by defendant's expert is itself a product of the employer's bais, reflecting a typical disparate treatment framework. Id. at 544. The court did not consider applying disparate impact analysis which would require the defendant to prove the business necessity of the factor in question.

127. 106 S. Ct. 3000 (1986) (per curiam).

128. Id. at 3003 (Brennan, J., concurring in part for a unanimous Court).

129. Id. (Brennan, J., concurring in part for a unanimous Court). 
Suit was filed in 1971. The Supreme Court noted that much of the plaintiffs' evidence at trial consisted of multiple regression analyses of wage rates. ${ }^{130}$ The plaintiffs used four explanatory factors: race, education, tenure, and job title. These analyses "purported to demonstrate" that race had a statistically significant effect on salary in 1974 and 1975.131 The district court ruled against the plaintiffs in all respects, and generally viewed the Extension Service as having conducted itself in a nondiscriminatory manner since it became subject to Title VII. ${ }^{132}$

On appeal, the Fourth Circuit upheld the district court's decision, reasoning that the Extension Service was under no obligation to eliminate any race-based salary disparity which originated prior to 1972 when Title VII became applicable to public employers. ${ }^{133}$ The court stated: "The plaintiffs claim that the pre-Act discriminatory difference in salaries should have been affirmatively eliminated but has not. We do not think this is the law."134 Thus, the court found that despite the admitted discriminatory wage system which was in place prior to Title VII, "the lingering effects of pre-Act discriminatory pay" 135 could not now be considered actionable. The Fourth Circuit upheld the district court's complete rejection of plaintiffs' multiple regression statistics, in part because they were based on data which included "pre-Act hires, both pre-1965 and pre-1972."136

The Fourth Circuit also affirmed the district court's rejection of plaintiffs' multiple regression analysis because of supposed missing factors in the analysis. The plaintiffs' expert "had not included a number of variable factors the court considered relevant." 137 The Fourth Circuit stated that "appropriate regression analysis of salary should . . . include all measurable variables thought to have an effect on salary level." 138

Fourth Circuit Judge Phillips wrote a strong dissent in which he opined that if salary differentials based on race extended into the applicable period of Title VII they were actionable. ${ }^{139}$ Furthermore, he was highly critical of the court's rejection of the multiple regression statistics for supposed missing factors hypothesized by the defendants. He stated that:

$[T]$ o apply such a rule generally would effectively destroy the ability to establish any Title VII pattern or practice claim by this means of proof. . . will always be possible for Title VII defendants to hypothesize yet another variable that might theoretically reduce a race-effect coefficient demonstrated by any multiple regression analysis that could be conceived. ${ }^{140}$

130. Id. at 3008 (Brennan, J., concurring in part for a unanimous Court).

131. Id. at 3008 n.9 (Brennan, J., concurring in part for a unanimous Court).

132. Id. at 3005 (Brennan, $\mathrm{J}$., concurring in part for a unanimous Court).

133. Bazemore v. Friday, 751 F.2d 662, 670 (4th Cir. 1984).

134. Id.

135. Id. at 671 .

136. Id. at 672 n.7.

137. Id. at 672.

138. Id. (emphasis added).

139. Id. at 695-96 (Phillips, J., dissenting).

140. Id. at 692-93. 
Judge Phillips also contended that to rebut the inference of discrimination raised by the regression analysis, the defendant should have presented "evidence that the inclusion of other relevant variables would in fact reduce the race-effect coefficient to a statistically insignificant level." 141 In this case, where the defendant's expert introduced one of the claimed missing factors into his own regression analysis, it in fact increased the demonstrated raceeffect. ${ }^{142}$

The Supreme court, in a per curiam opinion, unanimously reversed the Fourth Circuit's holding on wage discrimination, with reasoning parallel to Judge Phillips' dissent. ${ }^{143}$ Justice Brennan's concurrence in part for a unanimous Court was a strongly worded criticism of the Fourth Circuit's decision. In response to the Fourth Circuit's conclusion that the law did not require the elimination of the effect of pre-Act discrimination on salary rates, Justice Brennan stated:

The error of the court of Appeals with respect to salary disparities created prior to 1972 and perpetuated thereafter is too obvious to warrant extended discussion: that the Extention Service discriminated with respect to salaries prior to the time it was covered by Title VII does not excuse perpetuating that discrimination after the Extension Service became covered by Title VII. To hold otherwise would have the effect of exempting from liability those employers who were historically the greatest offenders of the rights of blacks. . . . While recovery may not be permitted for pre1972 acts of discrimination, to the extent that this discrimination was perpetuated after 1972, liability may be imposed.

Each week's pay check that delivers less to a black than to a similarly situated white is a wrong actionable under Title VII, regardless of the fact that this pattern was begun prior to the effective date of Title VII. ${ }^{144}$

This conclusion of the Supreme Court precisely corresponds with the Mark and Mary example of continuing wage discrimination, set out in Section III B of this article, and discussed at length in Section IV B. Clearly, under the Bazemore decision, Title VII plaintiffs will now have strong precedent for insisting that data on persons hired prior to the reach of the statute not be removed from the multiple regression data set. And wage differences based in part on pre-Act patterns of discrimination must not be permitted to persist in the actionable period.

In Bazemore, the Supreme Court also strongly criticized the Fourth Circuit's rejection of plaintiff's multiple regression statistics because of supposed missing factors. Justice Brennan stated:

The Court of Appeals erred in stating that petitioners' regression analyses were "unacceptable as evidence of discrimination," because they did not include "all measurable variables thought to have an effect on salary level." The court's view of the evidentiary value of the regression analyses was plainly incorrect. While the omission of variables from a regression analysis may render the analyses less probative than it otherwise might be, it can hardly be said, absent some other infirmity, that an analysis which accounts for the major factors "must be considered unacceptable as

141. Id. at 693 .

142. Id. at 693 n.7.

143. 106 S. Ct. 3000,3009 (1986) (per curiam) (Brennan, J., concurring in part for a unanimous Court).

144. Id. at 3006 (Brennan, J., concurring in part for a unanimous court) (emphasis in original). 
evidence of discrimination." Normally, failure to include variables will affect the analysis' probativeness, not its admissibility.

Importantly, it is clear that a regression analysis that includes less than "all measurable variables" may serve to prove a plaintiff's case. A plaintiff in a Title VII suit need not prove discrimination with scientific certainty; rather, his or her burden is to prove discrimination by a preponderance of the evidence. ${ }^{145}$

The Supreme Court has established that a logically prepared multiple regression analysis which indicates discrimination exists cannot be defeated by the mere claim of missing factors. The defendant must actually present statistics which prove that a suggested missing factor will, when included in the regression, eliminate the apparent discriminatory effect. ${ }^{146}$ Where the defendant does establish that such a factor reduces the discriminary effect, the plaintiff should still evalute the possible bias of that factor under the combined disparate treatment/impact standard set out in this article. ${ }^{147}$

The Supreme Court's clear respect for the evidentiary value of multiple regression analysis, as indicated in Bazemore, will undoubtedly lead to increased reliance on this statistical technique in the future. Title VII attorneys should take advantage of this powerful evidentiary tool.

145. Id. at 3009 (Brennan, J., concurring in part for a unanimous court) (citations omitted).

146. See id. at 3010-11\& n.14 (Brennan, J., concurring in part for a unanimous court).

147. See supra Section IV A. 